\title{
Feministička teorija između globalnog, regionalnog i lokalnog
}

\section{Lada Čale Feldman, Ana Tomljenović, Uvod u feminističku književnu kritiku, Leykam international d.o.o., Zagreb 2012, 292 s.}

Na početku ovog prikaza potrebno je reći da je knjiga Uvod u feminističku književnu kritiku Lade Čale Feldman i Ane Tomljenović na neki način proizvod višedecenijskog rada ,zagrebačke škole književne teorije”, koja nastaje sedamdesetih godina 20. stoleća i čiji su značajni predstavnici bili profesori rođeni 20 -ih i 30-ih godina, među kojima treba pomenuti Zdenka Škreba, Milivoja Solara, Aleksandra Flakera, Svetozara Petrovića (koji će biti značajan za srpsku teoriju književnosti, jer je kasnije delovao u Novom Sadu i Beogradu) i dr., čiji je rezultat rada bila višetomna Povijest svjetske književnosti, kao i njihovi individualni teorijski i istoričarski radovi. U narednoj generaciji pomenuću samo Vladimira Bitija sa njegovim pojmovnicima Pojmovnik suvremene književne teorije (1997) i prošireno izadnje objavljeno pod naslovom Pojmovnik suvremene književne $i$ kulturne teorije (2000). Tu je i generacija rođena oko 60-ih u kojoj bih pomenula Andreu Zlatar, Ladu Čale Feldman i niz teoretičarki okupljenih oko zagrebačkog Centra za ženske studije, od kojih su mnoge vezane ili su bile vezane za Institut za etnologiju i folkloristiku (pomenuću Renatu Jambrešić Kirin, Natašu Govedić, do mlađih poput Suzane Marjanić itd.). Među najmlađim aktivnim teoretičarkama nalaze se i Maša Grdešić, Ana Tomljenović i Maša Kolanović. Od kraja 90-ih u Zagrebu je nastala izuzetno produktivna feministička teorijska scena čiju su institucionalnu potporu, pored pomenutog centra, omogućili i časopisi „Treća” (Centar za ženske studije) i „Kruh i ruže” (Infoteka), sa pratećim edicijama koje su objavljujući najviše savremenu domaću produkciju omogućili ovaj izvanredan razvoj. 
Lada Čale Feldman ubraja se u srednju generaciju hrvatskih feminističkih teoretičarki koje imaju zavidnu teorijsku produkciju. Treba napomenuti da Uvod u feminističku književnu kritiku nije prva knjiga koju je realizovala u koautorstvu. Zanimljiv je bio teorijski projekt U kanonu (2008) koji je ostvarila sa sestrom, takođe istaknutom teoretičarkom, Moranom Čale. I dok su autorke knjige U kanonu pisale odvojene tekstove u dva paralelna teorijska glasa, spisateljski poduhvat sa Anom Tomljenović nastao je tako što su one svoje teoretičarske glasove spojile u jedinstveni koautorski glas. Nasuprot mom opisu, one ovaj poduhvat opisuju kao ,produkt autorskog višeglasja” (str. 15). Sigurno je da je ovaj postupak doprineo kompleksnosti knjige i možda omogućio širi raspon razmatranih teorijskih i književnih praksi. Knjigu možemo shvatiti i kao rezultat pregalaštva hrvatske književne teorije, čiji su protagonisti/protagonistkinje višedecenijskim nastojanjem kreirali dinamičnu teorijsku scenu čija je produkcija generalno prilično visokog kvaliteta. U hrvatskoj kulturi je tokom 90-ih u književnoj teoriji došlo, kao nikad ranije, do vidljivog teorijskog rada te stoga i uticaja brojnih teoretičarki (dok su ranijim periodima dominirali teoretičari), što je deo opšte tendencije da visoko obrazovanje preuzimaju žene. Autorke i same ističu da je njihova knjiga svojevrstan „dug nizu naših naraštajnih prethodnica i sadašnjih sugovornica, bez kojih bi je bilo nemoguće napisati” (str. 15). Period kada generacije teoretičarki rođenih od 60-ih nadalje ulaze u životnu i stvaralačku zrelost poklopio se sa društvenim promenama, padom socijalizma, raspadom SFRJ i ponovnim dolaskom feminističke teorije u ovaj deo sveta, ovog puta kao jednog od svetski hegemonih teorijskih diskursa.

$\mathrm{Na}$ početku još dva zapažanja. Iako je ovo, kako naslov kaže, Uvod u feminističke književne teorije, knjiga je složena i razrađena rasprava o problemima feminističkih teorija. Autorke prate trendove feminističke teorije globalno, pre svega u zapadnom svetu, obuhvatajući teorijske koncepte angloameričkih ginokritičarki, poststrukturalistkinja, lezbejskih i queer teoretičarki itd. Zatim se bave mapiranjem lokalnih teorijskih, istoričarskih, interpretativnih koncepata hrvatskih teoretičarki. Ono što dalje izaziva našu veliku pažnju, i zbog čega je knjiga značajna i za nas u Srbiji, jeste „politika citata” (termin Marine Blagojević Hjuston), koja je „,inkluzivna". Autorke se pozivaju ne samo na svetski priznata imena, već mapiraju feminističku teorijsku problematiku kod hrvatskih teoretičarki 
i teoretičara, a svoje očište proširuju i na regiju, te se u referencama nalaze brojne autorke iz Slovenije, Bosne i Hercegovine i Srbije. Tim postupkom pokazuju poštovanje prema koleginicama i kolegama, čiji rad pažljivo interpretiraju, pokazujući koliko se autorki i autora u hrvatskoj kulturi bavilo feminističkim i/ili šire ženskim temama. Možda je to i bilo moguće, jer ti opusi pripadaju sličnim diskurzivnim matricama ,savremenosti” i zato što postoji svest o tome da je neophodno pokazati koliko je teorijsko-kritičarsko polje sopstvene kulture razuđeno i bogato. Posežući za autorkama i autorima iz regije, one pokazuju kako su feminističke ,alijanse ostale možda najčvršćim sponama nedavno zaraćenih susjeda, njegujući kulturne poveznice svojedobne zajedničke «strukture osjećanja» mimo jugonostalgičnih političkih kalkulacija, i konzumerističke površnosti” (str. 13). U ovoj dimenziji uočava se teorijski aktivizam koji se na nivou ,politike teorije” pokazuje u svoj otvorenosti za saradnju i međusobnu regionalnu recepciju, koju povremeno osujećuju političke prilike „dugog” perioda (koji još traje i neizvesno je koliko će dugo još trajati) posle jugoslovenskih ratova (regionalna trauma, koja kao da se ne može, kao da se ne želi okončati). A baš se takva recepcija u doba globalizacije čini neophodnom. Problem je u odnosu malih književnosti i kultura prema na velikim, hegemonim kulturama. Ili kako naše autorke pišu,

u kontekstu naše diskusije o kanonu i sama se hrvatska književna tradicija, kako već zakratko pripomenusmo (...) doima u položaju ,ženske" ušutkanosti u europskom mnogoglasju kojemu se toliko nastojala pridružiti, osjećajući bolno do koje se mjere popisi književnih velikana diktiraju iz povijesno pomičnih centara kulturne, obrazovne, povrh svega političke i ekonomske moći. S obzirom da ista sudbina nužno prati i književnokritička tumačenja toga korpusa, i za njih vrijedi upozorenje da se nacionalna samosvijest nerijetko podupire reprodukcijom rodnih diskvalifikacija u vlastitome dvorištu (str. 121).

Jer postavlja se pitanje kako marginalizovane regione integrisati u globalne feminističke diskurse i tekuće rasprave, a ova nam knjiga demonstrira kako je to simbolički moguće učiniti. Čale Felman i Tomljenović su uspele proizvesti izuzetno složenu sintetičku studiju u kojoj ne samo da detaljno obrazlažuprobleme feminističkih studija od njihovih teorijskih početaka od drugog talasa feminizma 70-ih godina, ukazujući na brojne prethodnice sa početka 20. stoleća pa i ranije. To su učinile na poseban način, ističući lokalnu tradiciju i umećući je u globalne teorijske narative. 
Njihova metodologija je „mobilna”, ona stalno menja fokuse i istorijske periode i lokacije, te tako lokalna hrvatska ali i regionalne kulture postaju jedne od brojnih ,lokalnih nacionalnih kultura” u kojima dolazi do fenomena ženskog autorstva uz sve institucionalne prepreke o kojima feministkinje teoretiziraju. Mapirano je žensko stvaralaštvo u rasponu od narodne književnosti, koju proučava folkloristika, preko antike, srednjeg veka, renesanse, klasicizma, do modernog i savremenog doba.

Objašnjavajući da je književnost patrijarhalna insitucija, one ističu važnost ,povijesnih konstrukcija što su žensko stvaralaštvo minimizirale”, kao i „rodnih režima perioda” u kojima se književna povest stvara. Prateći i obrazlažući kako su nastajali nacionalni književni kanoni i kako su ih autorke iz različitih istorijskih perioda izazivale i kako ih je feminizam dovodio u pitanje, Čale Feldman i Tomljenović pokazuju udeo psihoanalize $\mathrm{u}$ feminističkom istraživanju književnosti, dolaze i do kulturalnih studija i njihovog rušenja razlike između visoke i popularnekulture. One ne samo da raspravljaju o različitim periodim, već se bavi i različitim žanrovima. U knjizi nalazimo detaljne rasprave o poeziji, prozi i drami, kao i filmu i performansu.

I mada je očigledno da regionalna međusobna recepcija feminističkih autorki postoji, ova ju je knjiga učinila mnogo sistematičnijom i nadam se da daje razlog mnogima od nas da tu međusobnu recepciju intenziviramo uprkos svim mogućim preprekama i upravo zbog njih. 